\title{
High-density Cultivation in the Production of Microbial Products
}

\author{
R. Subramaniam, ${ }^{\mathrm{a},{ }^{*}}$ V. Thirumal, ${ }^{\mathrm{a}}$ A. Chistoserdov, ${ }^{\mathrm{b}}$ \\ R. Bajpai, ${ }^{a}$ J. Bader, ${ }^{c}$ and M. Popovic ${ }^{c}$ \\ ${ }^{a}$ Department of Chemical Engineering, University of Louisiana \\ at Lafayette, Lafayette, LA 70503, USA \\ ${ }^{b}$ Department of Biology, University of Louisiana at Lafayette, \\ Lafayette, LA 70503, USA \\ 'Beuth University of Applied Sciences, Life Sciences \\ and Technology, Biotechnology, Berlin, Germany
}

doi: 10.15255/CABEQ.2018.1394

Microbial fermentation processes are of great importance for the production of many bioproducts. Even for established processes, improvements in product yield, productivity, and quality are always continually demanded. This is particularly true as the products mature from being novelty to high demand, even bulk, substances, as has been witnessed for several antimicrobial compounds. High-density cultivations have been found very useful in producing a large number of modern bioproducts. Selection of the mode of fermentation, operating conditions, and optimized media are important characteristic features for high cell density, productivity, as well as the commercial success of any microbial product. This contribution reviews some of the challenges and technologies investigated for high-density cultivation. Important aspects such as medium composition, reactor conditions, oxygen transfer, temperature, agitation, $\mathrm{pH}$, modes of operation, and feeding strategies for high-density cultivation are summarized in this review.

Keywords:

high-density cultivation, mode of fermentation, medium composition, reactor conditions, biomass

\section{Introduction}

Large-scale culturing of microorganisms possessing biochemical pathways for desired products has enabled production of compounds such as enzymes, alcohols, amino acids, antibiotics, organic acids, and other biologically active compounds in quantities that might otherwise have been very difficult to obtain from natural sources or by chemical synthesis. Lately, new constructs of microbial production strains are being devised to even secrete the recombinant proteins ${ }^{1}$. As the products mature, process economics demands increasing volumetric productivity (i.e., production per unit volume per unit time; a product of active cell density and the specific cell productivity), which is a major goal of modern bioprocesses ${ }^{2-4}$. While metabolic engineering and regulation of biochemical pathways are utilized to increase specific cell productivity ${ }^{5-7}$, high-density cultivations are designed to achieve high product concentrations in broth via growing cells to high densities while maintaining high specific cell productivity. As a result, high-density cultivation (HDC) has become an important tool in modern bi-

"Corresponding author: Ramalingam Subramaniam, Email: raams@louisiana.edu; raams76@gmail.com oprocessing. This review concerns with the different issues involved in HDC of microorganisms.

High cell density is a relative term and no exact concentration of dry cell weight is considered representative of the process. In general, cell concentrations an order of magnitude or more than those achieved in conventional cultivation processes have been considered as high cell densities ${ }^{8}$. Per Tapia et $a l .^{8}$, cell concentration in the order of $10^{7}$ cells $\mathrm{mL}^{-1}$ is representative of high cell density. On the other hand, other studies have used dry cell weight densities ranging from $20 \mathrm{~g} \mathrm{~L}^{-19}$ to $50 \mathrm{~g} \mathrm{~L}^{-1}{ }^{10}$, and as high as to $200 \mathrm{~g} \mathrm{~L}^{-111}$ and $300 \mathrm{~g} \mathrm{~L}^{-112}$, to designate a high-density cultivation.

In the same note, although HDC research was initially mostly concerned with cultivation of Escherichia coli ${ }^{7},{ }^{13-17}$, high cell densities have been achieved with several other organisms as well with improved product accumulation. The bacterium $\mathrm{Ba}$ cillus megaterium ${ }^{18}$, the yeasts Rhodococcus opacus $^{19}$, Pichia pastoris ${ }^{20}$ and Candida rugosa ${ }^{21}$, the diatom Nitzchia laevis ${ }^{22}$, the algae Chlorella vulgar$i s^{23}$ and Nannochloris atomus Butcher ${ }^{24}$, the plant cells Panax notoginseng ${ }^{25}$ and other cell cultures ${ }^{8}$ have shown enhanced cell densities. The specific details of several HDC studies and their product yields are in Table 1. 
Table 1 -High-density cultivations adopted for different product formations: The maximum cell mass and product obtained from different species

\begin{tabular}{|c|c|c|c|c|c|}
\hline Cell & Product & Cell mass & Product & Method & Ref. \\
\hline Methylobacterium extorquens & Poly(3-Hydroxybutyrate) & $115 \mathrm{~g} \mathrm{~L}^{-1}$ & $52.9 \mathrm{~g} \mathrm{~L}^{-1}$ & OTR based fed-batch & 73 \\
\hline Zobellella denitrificans MW1 & Poly(3-Hydroxybutyrate) & $54 \mathrm{~g} \mathrm{~L}^{-1}$ & $36.4 \mathrm{~g} \mathrm{~L}^{-1}$ & $\begin{array}{l}\text { Medium-optimized fed-batch } \\
\text { cultivation }\end{array}$ & 96 \\
\hline Bacillus megaterium BA-019 & Poly(3-hydroxybutyrate) & $72.6 \mathrm{~g} \mathrm{~L}^{-1}$ & $30.5 \mathrm{~g} \mathrm{~L}^{-1}$ & $\begin{array}{l}\text { Medium-optimized fed-batch } \\
\text { cultivation }\end{array}$ & 18 \\
\hline Ralstonia eutropha & Poly(3-Hydroxybutyrate) & $300 \mathrm{~g} \mathrm{~L}^{-1}$ & N/A & DO stat fed-batch & 12 \\
\hline Rhodococcus opacus PD630 & TAG & $77.6 \mathrm{~g} \mathrm{~L}^{-1}$ & $27.6 \mathrm{~g} \mathrm{~L}^{-1}$ & Medium-optimized batch culture & 19 \\
\hline Crypthecodinium cohnii & $\begin{array}{l}\text { Lipid } \\
\text { Docosahexanoic acid }\end{array}$ & $109 \mathrm{~g} \mathrm{~L}^{-1}$ & $\begin{array}{l}61 \mathrm{~g} \mathrm{~L}^{-1} \\
19 \mathrm{~g} \mathrm{~L}^{-1}\end{array}$ & DO stat fed-batch & 77 \\
\hline Nitzschia laevis & Eicosapentanoic acid & $40 \mathrm{~g} \mathrm{~L}^{-1}$ & $1.1 \mathrm{~g} \mathrm{~L}^{-1}$ & Perfusion fed-batch & 22 \\
\hline Saccharomyces cerevisiae & Ergosterol & $120 \mathrm{~g} \mathrm{~L}^{-1}$ & $1500 \mathrm{mg} \mathrm{L}^{-1}$ & $\begin{array}{l}\text { Glucose-controlled fed-batch } \\
\text { cultivation }\end{array}$ & 97 \\
\hline Kluyveromyces marxianus & Ethanol & $60 \mathrm{~g} \mathrm{~L}^{-1}$ & $16 \mathrm{~g} \mathrm{~L}^{-1}$ & $\mathrm{pH}$ stat fed-batch & 85 \\
\hline $\begin{array}{l}\text { Saccharomyces cerevisiae } \\
\text { KV-25 }\end{array}$ & Biomass & $187.63 \mathrm{~g} \mathrm{~L}^{-1}$ & $\mathrm{~N} / \mathrm{A}$ & $\begin{array}{l}\text { Medium-optimized fed-batch } \\
\text { cultivation }\end{array}$ & 93 \\
\hline Candida utilis CBS 621 & Biomass & $90 \mathrm{~g} \mathrm{~L}^{-1}$ & $\mathrm{~N} / \mathrm{A}$ & Maltose feedstock & 51 \\
\hline Chlorella sp. NCTU-2 & Biomass & $5.15 \mathrm{~g} \mathrm{~L}^{-1}$ & $\mathrm{~N} / \mathrm{A}$ & Porous centric-tube photobioreactor & 90 \\
\hline Taxus chinensis & Paclitaxel & $22 \mathrm{~g} \mathrm{~L}^{-1}$ & $137.5 \mathrm{mg} \mathrm{L}^{-1}$ & Intermittent feeding fed-batch & 98 \\
\hline Pichia pastoris & Human cystatin & $125 \mathrm{~g} \mathrm{~L}^{-1}$ & $0.78 \mathrm{~g} \mathrm{~L}^{-1}$ & Fed-batch cultivation & 20 \\
\hline Pichia pastoris & Hepatitis B surface antigen & $97 \mathrm{~g} \mathrm{~L}^{-1}$ & $0.2 \mathrm{~g} \mathrm{~L}^{-1}$ & Continuous fermentation & 99 \\
\hline Methylobacterium extorquens & Green Fluorescent Protein & $56 \mathrm{~g} \mathrm{~L}^{-1}$ & $4 \mathrm{~g} \mathrm{~L}^{-1}$ & OTR based fed-batch & 10 \\
\hline Escherichia coli & Green Fluorescent Protein & $90 \mathrm{~g} \mathrm{~L}^{-1}$ & $1.3 \mathrm{~g} \mathrm{~L}^{-1}$ & Fed-batch cultivation & 38 \\
\hline Escherichia coli & Recombinant protein & $172 \mathrm{~g} \mathrm{~L}^{-1}$ & $0.3 \mathrm{~g} \mathrm{~L}^{-1}$ & Fed-batch cultivation & 100 \\
\hline Escherichia coli & Recombinant protein & $70 \mathrm{~g} \mathrm{~L}^{-1}$ & $6 \mathrm{~g} \mathrm{~L}^{-1}$ & $\begin{array}{l}\text { Fed-batch cultivation with stress } \\
\text { minimizing method }\end{array}$ & 64 \\
\hline Escherichia coli & Recombinant protein & $15 \mathrm{~g} \mathrm{~L}^{-1}$ & $\mathrm{~N} / \mathrm{A}$ & $\begin{array}{l}\text { Enzymatically controlled fed-batch } \\
\text { cultivation }\end{array}$ & 34 \\
\hline Escherichia coli & Recombinant protein & $20 \mathrm{~g} \mathrm{~L}^{-1}$ & N/A & Rocking motion type bioreactor & 17 \\
\hline Pichia pastoris & Recombinant protein & $>200 \mathrm{~g} \mathrm{~L}^{-1}$ & $6.5 \mathrm{~g} \mathrm{~L}^{-1}$ & Glucose-limited fed-batch cultivations & 11 \\
\hline Kluyveromyces marxianus & Betagalactosidase & $105 \mathrm{~g} \mathrm{~L}^{-1}$ & $2.2 \mathrm{~g} \mathrm{~L}^{-1}$ & Fed-batch & 9 \\
\hline Hansenula polymorpha & Levansurcrase & $120 \mathrm{~g} \mathrm{~L}^{-1}$ & $12.2 \mathrm{U} \mathrm{mL}^{-1}$ & DO stat fed-batch & 87 \\
\hline Brevibacterium linens & Proteinase & $50 \mathrm{~g} \mathrm{~L}^{-1}$ & $0.2 \mathrm{U} \mathrm{mL}^{-1}$ & Transitional feeding & 86 \\
\hline Kluyveromyces marxianus & $\beta$-Galactosidase & $105 \mathrm{~g} \mathrm{~L}^{-1}$ & $5.7 \mathrm{U} \mathrm{mg}^{-1}$ & Exponential feeding fed-batch & 101 \\
\hline Ralstonia eutropha & Organophosphohydrolase & $182 \mathrm{~g} \mathrm{~L}^{-1}$ & $4.3 \mathrm{~g} \mathrm{~L}^{-1}$ & Fed-batch cultivation & 102 \\
\hline Pichia pastoris & Alpha amylase & $110 \mathrm{~g} \mathrm{~L}^{-1}$ & $340 \mathrm{mg} \mathrm{L}^{-1}$ & DO stat fed-batch & 103 \\
\hline Pichia pastoris & Bovine entrokinase & $45 \mathrm{~g} \mathrm{~L}^{-1}$ & $9000 \mathrm{U} \mathrm{mg}^{-1}$ & $\mathrm{pH}$ stat fed-batch & 104 \\
\hline Pichia pastoris & Lipase & $50.4 \mathrm{~g} \mathrm{~L}^{-1}$ & $385 \mathrm{AU} \mathrm{mL}^{-1}$ & Specific growth rate control & 105 \\
\hline Candida rugosa & Lipase & $5.9 \mathrm{~g} \mathrm{~L}^{-1}$ & $117 \mathrm{U} \mathrm{mL}^{-1}$ & Constant feeding & 21 \\
\hline Yarrowia lipolytica & Lipase & $1.79 \mathrm{~g} \mathrm{~L}^{-1}$ & $2016 \mathrm{U} \mathrm{mL}^{-1}$ & Fed-batch cultivation & 57 \\
\hline Candida cylindracea & Lipase & $90 \mathrm{~g} \mathrm{~L}^{-1}$ & $23.7 \mathrm{U} \mathrm{mL}^{-1}$ & Specific growth rate control & 56 \\
\hline Schizosaccharomyces pombe & Lipase & $>50 \mathrm{~g} \mathrm{~L}^{-1}$ & $16 \mathrm{U} \mathrm{mL}^{-1}$ & Specific growth rate control & 83 \\
\hline Hansenula polymorpha & Human serum albumin & $83 \mathrm{~g} \mathrm{~L}^{-1}$ & $550 \mathrm{mg} \mathrm{L}^{-1}$ & DO stat fed-batch & 106 \\
\hline Escherichia coli & Gluthathione & $80 \mathrm{~g} \mathrm{~L}^{-1}$ & $880 \mathrm{mg} \mathrm{L}^{-1}$ & Exponential feeding fed-batch & 107 \\
\hline Panax notoginseng & Ginseng saponin & $27.3 \mathrm{~g} \mathrm{~L}^{-1}$ & $0.55 \mathrm{~g} \mathrm{~L}^{-1}$ & Fed-batch & 25 \\
\hline
\end{tabular}


For a HDC to be viable, the species must be capable of growing within process equipment constraints (such as heat and oxygen transfer capacities, mixing, shear, etc.), as well as tolerating any metabolic products formed. The advantages of HDC include increased cost effectiveness, reduced culture volume, enhanced downstream processing, reduced wastewater production, lower production costs, and reduced capital requirements ${ }^{13}$. The problems associated with HDC include product inhibition $^{26-28}$, limited oxygen ${ }^{29}$ and heat $\operatorname{transfer}^{30}$ capaci- $^{-}$ ties of processing equipment, and formation of unwanted by-products ${ }^{26,31-33}$. While the problems may seem substantial, many of them can be overcome through careful considerations in the design and operation of the process. This review focuses on recent approaches utilized in HDC as well as to solve the problems that have been associated with HDC to achieve increased productivity either through increased cell density or specific productivity or both. The primary focuses of this review are on the medium composition, modes of operation and feeding schedules, reactor conditions such as oxygen transfer, temperature, agitation, and $\mathrm{pH}$. Furthermore, actual research about the stress reaction of the utilized microorganisms are discussed to improve HDC processes.

\section{Cell growth and medium optimization}

Microorganisms experience various limiting conditions when grown as HDC. Cells in high-density cultures face conditions such as nutrient depletion, elevated osmotic pressures, increased viscosity, limited oxygen transfer capacity, and local as well as temporal variations in concentrations of nutrients, temperature, agitation, and $\mathrm{pH}$. Proportionately large amounts of the substrate and nutrients are required for achieving high cell densities and increased product concentrations. Even if the requisite amounts can be incorporated in the medium at one time, the high concentrations may be toxic to cell growth. For example, E. coli growth was inhibited ${ }^{27}$ when the concentration of glucose, ammonia, iron, magnesium, phosphorus, and zinc exceeded, respectively, $50 \mathrm{~g} \mathrm{~L}^{-1}, 3 \mathrm{~g} \mathrm{~L}^{-1}, 1.15 \mathrm{~g} \mathrm{~L}^{-1}, 8.7 \mathrm{~g} \mathrm{~L}^{-1}$, $10 \mathrm{~g} \mathrm{~L}^{-1}$ and $0.038 \mathrm{~g} \mathrm{~L}^{-1}$. Therefore, controlled feeding strategy is usually employed as described further herein. Additionally, excess carbon source can result in formation of metabolic by-products that can inhibit cell growth and/or reduce carbon efficiency. Some common metabolic byproducts are acetate for E. coli, propionate for Bacillus spp., ethanol for $S$. cerevisiae ${ }^{33}$, and exopolysaccharides for Lypomyces starkeyi ${ }^{31,32}$. In high-density cultivation of Lypomyces starkeyi, exopolysaccharide production was observed when the glucose concentration exceeded $90 \mathrm{~g} \mathrm{~L}^{-131,32}$. Maintaining a low concentra- tion of glucose through intermittent or continuous feeding can mitigate this byproduct formation or minimize it.

Of course, strains capable of withstanding high substrate, nutrient, and/or product concentrations are very desirable or even necessary as in the case of $S$. cerevisiae, for which the product itself becomes inhibitory when its exogenous concentration exceeds $70 \mathrm{~g} \mathrm{~L}^{-1}{ }^{26}$. Kurosawa et al. ${ }^{19}$ reported that Rhodococcus opacus PD630 could grow in defined media supplemented with glucose up to a concentration of $300 \mathrm{~g} \mathrm{~L}^{-1}$ in batch culture. $R$. opacus PD630 grown in batch-culture with an optimal production medium containing $240 \mathrm{~g} \mathrm{~L}^{-1}$ glucose and $13.45 \mathrm{~g} \mathrm{~L}^{-1}\left(\mathrm{NH}_{4}\right)_{2} \mathrm{SO}_{4}$ (for $\mathrm{C} / \mathrm{N}$ ratio of 17.8 ) yielded $77.6 \mathrm{~g} \mathrm{~L}^{-1}$ of cell dry weight composed of approximately $38 \%$ TAGs.

For small-scale batch operation, several technologies involving novel growth media have been introduced ${ }^{16,17,34}$. Herein, slow release of growth substrates is achieved through use of slow-release polymers $\left(\right.$ FeedBeads ${ }^{\circledR}$, FeedPlates $^{\circledR}$ ) or through enzymatic degradation of polymers (EnBase ${ }^{\circledR}$ technology). Using a complex medium supplemented with peptone and yeast extract, 10-fold increase in volumetric productivity over conventional Luria broth medium for production of recombinant proteins by E. coli 1 has been reported using the EnPresso ${ }^{\circledR}$ system $^{16,34}$. An extensive review of these intelligent media' for production of recombinant proteins has been provided by Krause et al. ${ }^{34}$

However, the use of complex medium components such as peptone and yeast extract is often discouraged since their composition and quantity can vary from batch to batch, and thus pose issues of reproducibility in production processes. Media with known nutrient composition permit accurate control of cellular environment ${ }^{35}$ and are, therefore, favored in industrial large-scale operations. This is often combined with supplementation of certain amino acids to improve productivity. In the case of E. coli, $\beta$-isopropylmalate dehydrogenase activity was improved with the addition of a dose of $1 \mathrm{~g} \mathrm{~L}^{-1}$ leucine at the beginning of the culture ${ }^{36}$. S. cerevisiae has also shown improved protein production in a defined medium supplemented with alanine, arginine, asparagine, glutamic acid, glutamine, and glycine ${ }^{37}$. However, the value of the product and cost factor must be considered when adding amino acids.

Use of defined media is, however, not without its own pitfalls, and requires medium optimization and tweaking of feeding strategies in high-density cultivations. As an example, Beckmann et al. ${ }^{38}$ reported Leucine was inhibitory to leucine-auxotrophic Escherichia coli K12 ER2507 even at a concentration of $0.3 \mathrm{~g} \mathrm{~L}^{-1}$. This effect could be overcome by optimizing the feeding strategy and medium 
composition. Lau et al. ${ }^{39}$ reported that high cell-density fed-batch bioprocess for the heterologous production of 6-deoxyerythronolide B in Escherichia coli using a defined medium resulted in accumulation of excess. Following optimization of the medium composition and fermentation conditions, the maximum cell density was increased by two-fold. Overall, the fed-batch process represented an 11fold improvement over the batch process. This was achieved by maintaining the glucose and propionate levels in the bioreactor between 5 and $15 \mathrm{~g} \mathrm{~L}^{-1}$, and 20 and $40 \mathrm{nM}$, respectively, and by feeding 565 mmol d ${ }^{-1}$ ammonium sulfate.

Selection and optimization of appropriate medium components is critical to successful operation of HDC. During high-density cultivation, the cells may experience environmental stress, limitations of nutrients, and even changes in metabolic states. Hence, the medium should be optimized to ensure that all the nutrients are available in sufficient quantities for cellular growth and suitable for downstream processing. Burgard et al. ${ }^{40}$ found that methanol-and glucose-grown cultures of Pichia pastoris experienced transcriptional upregulation of genes connected to phosphorus and sulfur metabolism from the middle to the end of the fed-batch. The genes connected to transport processes utilized alternative substrates to cover the phosphorus nitrogen, and sulfur limitation. Addition of proper supplementation countered the upregulation resulting in significant improvements in cell growth and recombinant protein expression. Selection of appropriate substrate too is critical. As an example, although methanol or methanol/glycerol mixtures have been used for production of heterologous proteins in Pichia pastoris in high-density cultivations, using methanol as carbon source has potential for cell lysis and explosion hazard during commercial operation $^{11}$. To avoid this, methanol may be substituted with glucose as sole carbon source in high-density cultivation of $P$. pastoris for recombinant protein production as demonstrated by Heyland et al. ${ }^{11}$ Using a recombinant $P$. pastoris strain in glucose-limited fed-batch cultivations, over $200 \mathrm{~g} \mathrm{~L}^{-1}$ of dry cell weight (CDW) concentration was achieved resulting in a recombinant protein, Bap A, titer of $6.5 \mathrm{~g} \mathrm{~L}^{-1}$.

Another consideration in the preparation of media is the solubility of certain medium ingredients, especially when they are added in large concentrations. Presence of phosphates, sulfates, chloride, sodium, calcium, ammonium, and magnesium in the medium has the possibility of forming non-soluble complexes such as ammonium phosphate, magnesium phosphate, calcium phosphate, and other metal phosphates during sterilization as well as during the fermentation process due to the production of organic acids and carbon dioxide. These complexes may precipitate ${ }^{14}$. Precipitation can pose an issue when it comes to downstream processing, such as purification as well as monitoring devices. Precipitation can also complicate the process of measurement and monitoring not only mineral concentrations but also cell densities ${ }^{41}$. Furthermore, high salt concentrations pose additional issues, such as osmotic pressure and conductivity that affect membrane stability and may result in a reduction of growth rate ${ }^{42}$.

Brady et al..$^{43}$ presented a simplistic solution to such issues by simply reducing the salt concentrations to a quarter of the recipe of the medium, although that is not equally applicable to many species. As salt precipitation is a common problem during $P$. pastoris high-density fermentation due to the accumulation of certain lipids, Brady et al..$^{43}$ used a low-salt, fully defined medium for the production of the full-length P30P2MSP1-19 (a recombinant subunit vaccine for malaria) in Pichia pastoris, that did not reduce growth rates or biomass yields on either glycerol or methanol utilized to avoid precipitation. A total of $500 \mathrm{mg} \mathrm{L}^{-1}$ of secreted purified protein was produced in high cell density fermentation from a wet cell weight of $180 \mathrm{~g} \mathrm{~L}^{-1}$. Similarly, Yup et al. ${ }^{44}$ reported that, decreasing the phosphorus concentration by reducing initial $\mathrm{KH}_{2} \mathrm{PO}_{4}$ (from $7.5 \mathrm{~g} \mathrm{~L}^{-1}$ to $4 \mathrm{~g} \mathrm{~L}^{-1}$ ) during a fedbatch culture of Pseudomonas putida, could result in increased formation of polyhydroxyalkanoate (from $32.3 \mathrm{~g} \mathrm{~L}^{-1}$ to $72.6 \mathrm{~g} \mathrm{~L}^{-1}$ ). Conversely, Lau et al. ${ }^{39}$ doubled the concentration of phosphate, in addition to a propionate-controlled feed, to achieve doubled cell concentrations and an eleven-fold increase in production of 6-deoxyerythronolide B.

Identification and delivery of appropriate nutrients is critical to achieving high product titers in high-density cultivation. As an example, López et $a l .{ }^{45}$ found that, although a relatively high cell density (29.9 $\left.\mathrm{g} \mathrm{L}^{-1}\right)$ of Zobellella denitrificans MW1 could be obtained in only a short period $(24 \mathrm{~h})$ during fed-batch operation feeding glycerol, the production of Poly(3-Hydroxybutyrate) was relatively low $\left(9.3 \mathrm{~g} \mathrm{~L}^{-1}\right)$. Much higher concentrations of PHB (up to $54.3 \mathrm{~g} \mathrm{~L}^{-1}$ ) and higher cell densities (up to $81.2 \mathrm{~g} \mathrm{~L}^{-1}$ ) were obtained by fed-batch operation in the presence of $20 \mathrm{~g} \mathrm{~L}^{-1} \mathrm{NaCl}$ coupled with optimized feeding of glycerol and ammonia to support both cell growth and polymer accumulation over a period of $50 \mathrm{~h}$. A high specific growth rate $\left(0.422 \mathrm{~h}^{-1}\right)$ and a short doubling time $(1.64 \mathrm{~h})$ were attained. Similarly, Kim et al. ${ }^{46}$ utilized an ammonia-restriction feeding strategy to enhance the PHB production in a fed-batch culture of Alcaligenes eutrophus with broth glucose concentration control in the range of 10 to $20 \mathrm{~g} \mathrm{~L}^{-1}$. The final cell concentra- 
tion, PHB concentration and PHB productivity increased as feeding of ammonia was stopped at the cell concentration of $70 \mathrm{~g} \mathrm{~L}^{-1}$ (cell yield $\sim 0.43 \mathrm{~g} \mathrm{~g}^{-1}$ glucose). Final concentrations of PHB $\left(121 \mathrm{~g} \mathrm{~L}^{-1}\right)$ and total cells $\left(164 \mathrm{~g} \mathrm{~L}^{-1}\right)$ were obtained in $50 \mathrm{~h}$ (cell yield $\sim 0.38 \mathrm{~g} \mathrm{~g}^{-1}$ glucose). For the production of a polyhydroxyalkanoate (PHA) using Ralstonia eutropha, Riedel et al. ${ }^{47}$ developed a high cell density cultivation fed-batch process using fructose or palm oil as a carbon source and nitrogen limitation to induce PHA accumulation. The feed of carbon source was $\sim 170 \mathrm{~g} \mathrm{~L}^{-1}$. This fermentation resulted in a biomass concentration of $139 \mathrm{~g} \mathrm{~L}^{-1}$ cell dry weight with $74 \%$ of dry cell weight as PHA containing 19 mol\% poly(3-hydroxybutyrate-co-3-hydroxyhexanoate) with PHA productivity of $1 \mathrm{~g} \mathrm{~L}^{-1} \mathrm{~h}^{-1}$.

Thus, media optimization and the optimization of the feeding profile can be a highly valuable avenue of research in establishing the optimal conditions to obtain HDC. While early approaches were trial and error processes, statistical techniques such as Response Surface Methodology (RSM) or factorial design can provide a more organized avenue for the Design of Experiments (DOE). Beckmann et $a l^{38}$ applied full factorial design of experiments to optimize the concentration of glucose and leucine in the feed medium and achieved a cell density of 97 $\mathrm{g} \mathrm{L}^{-1}$ for the leucine auxotrophic E. coli strain $\mathrm{K} 12$ ER2507. Subramaniam et al. ${ }^{48-50}$ developed a minimal medium by replacing costly yeast extract with vitamins such as biotin, calcium pantothenol and inositol. They utilized RSM to optimize the concentrations of vitamins and phosphates. With the optimized minimal medium, Subramaniam et al. ${ }^{48-50}$ could reduce the medium cost for lipid production by Lipomyces starkeyi from $\$ 12.68$ per gallon lipids to $\$ 3.11$ per gallon lipids with high cell density of $44.5 \mathrm{~g} \mathrm{~L}^{-1}$ and lipid concentration of $33.5 \mathrm{~g} \mathrm{~L}^{-1}$.

\section{Reactor operation}

Since the environmental conditions importantly affect cell growth as well as product formation, the success of high-density cultivation is dependent on choosing an optimal method of reactor operation. Several different methods have been developed for supplying nutrients to cells in culture. The key consideration when choosing a method is to ensure that the concentrations of substrate(s) and nutrients are maintained within the desired range to avoid overfeeding or underfeeding. While batch ${ }^{51}$ and continuous mode of operation have been utilized, fed-batch operation is most commonly used in HDC.

\section{Fed-batch operation}

Fed-batch cultivation involves a semi-batch operation of bioreactor in which the nutrients neces- sary for cell growth and product formation are fed continuously or intermittently into the reactor. The culture broth is typically harvested only at the end of the operational period, either fully or partially, with the remainder serving as the inoculum for the next run. Through the manipulation of feeding and withdrawals, the fed-batch operation can provide unique means of regulating the broth concentration of compounds that control the key metabolic pathways and, therefore, possess definite advantages over batch or continuous operation. The fed-batch process is particularly useful for HDC due to the control of substrate concentration that is necessary, as well as increasing the working time for growth-related product formation.

Shiloach and Fass ${ }^{14}$ have discussed several different strategies that can be used to achieve HDC for E. coli. Continuous and constant rate of feeding utilizes addition of nutrients into the bioreactor at a specified rate. Under substrate-limited conditions of growth in such feeding strategy, the specific growth rate of cells decreases, and cell concentration increases also slow down ${ }^{52}$ since the volume of reactor contents increases constantly. On the other hand, variable feed rates may provide some advantages depending on the situation. Jensen and Carlsen ${ }^{52}$ reported that a gradual increase in the feeding rate could mitigate the effects of increased volume and enhance cell growth by supplying more nutrients. A feeding rate (of the limiting substrate) that is related to the cell concentration can allow for an extension of the exponential growth phase. This exponential feeding method can be used to allow cells to grow at constant specific growth rates. ${ }^{14}$ When the growth characteristics of an organism are known, the exponential feeding rate can be tailored to provide the optimal metabolic condition, resulting in maximal productivity ${ }^{53-55}$. Kim and $\mathrm{Hou}^{56}$ compared intermittent feeding of oleic acid (where the substrate was added to bring its concentration back to initial concentration after a certain time) with stepwise feeding (designed to simulate exponential feeding to support specific growth rate of cells) in fed-batch cultures of Candida cylindracea to improve cell concentration and lipase activity. In intermittent feeding with oleic acid added after $26.5 \mathrm{~h}$ from cultivation start to the initial oleic acid concentration of $50 \mathrm{~g} \mathrm{~L}^{-1}$, the final cell concentration was $52 \mathrm{~g} \mathrm{~L}^{-1}$ and the extracellular lipase activity was $6.3 \mathrm{U} \mathrm{mL}^{-1}$ at $138.5 \mathrm{~h}$. In stepwise feeding simulating a constant specific growth rate of $0.02 \mathrm{~h}^{-1}$, the highest final cell concentration obtained was $90 \mathrm{~g} \mathrm{~L}^{-1}$ and the extracellular lipase activity of $23.7 \mathrm{U} \mathrm{mL}^{-1}$, showing clearly the importance of selecting the optimal feeding strategy for maximal product formation. 
Feeding an inducer at appropriate stages of fedbatch operation is commonly employed to enhance expression of products. Fickers et al. ${ }^{57}$ reported that feeding of complete glucose medium in a fed-batch culture of Yarrowia lipolytica resulted in a 2-fold increase in lipase production compared to batch cultivation. But when olive oil was also added to the glucose medium during feeding, the lipase production increased three-fold that of batch culture. In another study, intermittent feeding of $12 \%$ glycerol solution resulted in $83 \mathrm{~g} \mathrm{~L}^{-1}$ dry cell weight with human serum albumin production of $550 \mathrm{mg} \mathrm{L}^{-1}$ in less than $32 \mathrm{~h}$ of fed-batch cultivation of Hansenula polymorpha having the glyceraldehyde-3-phosphate dehydrogenase promoter to express $\mathrm{HSA}^{58}$. JooHyung et $a l .{ }^{58}$ also reported that addition of glycerol was more stimulatory to the production than having only glucose or methanol. Similarly, Choi et al. ${ }^{59}$ also noted that paclitaxel production in suspension culture of Taxus chinensis cells could be enhanced by utilizing an intermittent feeding strategy of sucrose, but intermittent feeding of maltose as carbon source was much more stimulatory. Twenty-six milligrams per liter paclitaxel production was achieved through the intermittent feeding of 3,1 , and $2 \%$ $(\mathrm{w} / \mathrm{v})$ sucrose at 0,7 , and 21 days, respectively. Sixty-seven milligrams per liter paclitaxel production was achieved through the intermittent feeding of 1 and $2 \%(\mathrm{w} / \mathrm{v})$ maltose at 7 and 21 days, respectively. On the other hand, use of fructose in high-density cultures did not prove beneficial.

\section{Two-stage cyclic fed-batch operation}

Shin et al. ${ }^{60}$ studied the production of human mini-proinsulin through a two-stage fed-batch fermentation process to achieve a high cell density of Escherichia coli. This two-stage fed-batch operation, a modification of the fed-batch process, consisted of a growth tank and an induction tank where the product formation took place. The cells were grown in the growth tank, and a portion of the cell broth was transferred to the induction tank, while leaving a small volume of cell broth in the growth tank for continued cell growth. The volume of liquid in the growth tank was refilled to its pretransfer volume while product formation was taking place in the induction tank. By separating the growth and production phases of cell cultivation, the culture conditions, such as temperature, $\mathrm{pH}$, and medium compositions could be defined to a state ideal for each process. By applying this two-stage fed-batch fermentation process to produce human mini pro insulin by Escherichia coli, up to $44 \%$ increase in volumetric productivity was achieved from single-stage fed-batch fermentation where productivity was $0.175 \mathrm{~g} \mathrm{~L}^{-1} \mathrm{~h}^{-1}$. Such a process design is very attractive as it may lead to a continuous fermenta- tion process for recombinant DNA products with decreased down-times and reduced downstream costs. FDA encourages pharma companies to develop continuous processes to achieve higher product quality ${ }^{61}$. In the case of Yarrowia lipolytica SMY2, the use of this process led to a two-fold increase in volumetric productivity of rice $\alpha$-amylase production compared to a conventional fed-batch reactor ${ }^{21}$. However, these benefits need to be balanced with increased complexity of operation, potential for contamination, losses due to strain instability, and ultimately increases capital costs.

\section{Temperature-limited fed-batch reactor}

A unique approach to the fed-batch process is the use of temperature to control growth as opposed to the conventional use of substrate feeding rates. By utilizing a gradual decrease in temperature, Jahic et al. ${ }^{62}$ found that a higher accumulation of protein can be achieved through to a combination of reduced protein inactivation due to thermolysis and reduced cell death resulting in reduced proteinase release. De Maré et al. ${ }^{29}$ used cultivation combining a temperature-limited fed-batch process with feed control to achieve a $20 \%$ increase in cell mass. Temperature gradients may also lead to a higher fraction of soluble proteins since high temperatures cause a high amount of inclusion bodies and low temperatures result in a higher amount of soluble fraction ${ }^{63}$.

Temperature control is already of major concern in industrial applications of microbial fermentation, and it poses a much more important role in high-density cultivation due to two factors that are directly caused by high-density cultivation: increased heat generation, and reduced heat transfer. The increase in heat generation is simply a function of the increased cell density, resulting from the metabolic processes, while the reduction in heat transfer is caused by an increase in viscosity that tends to accompany high-density cultivation. Donovan et $a l .{ }^{30}$ demonstrated that temperature affects the yield of proteins in culture, and a reduction in culture temperature can be a simple method of increasing protein production. Also, Wyre and Overton ${ }^{64}$ suggest an adapted temperature profile for the improved production of soluble proteins by the reduction of stress through reduced temperature during the production of recombinant proteins.

\section{Dialysis reactors}

In the case of unavoidable inhibitory effects of nutrients or byproducts, a method to reduce the effective concentrations of the substances can prove beneficial. Dialysis can be a way to overcome this limitation. Dialysis is the separation of broth com- 
ponents dissolved in a liquid by differences in their ability to pass through a semi-permeable membrane driven by a concentration differential. Shiloach and Fass $^{14}$ have reported two such reactor configurations to achieve high-density cultivations. One design utilizes a separate reactor and reservoir connected by a dialysis machine, and the other has a single reactor that uses a membrane to create two compartments. Nakano et al. ${ }^{65}$ reported that a membrane dialysis bioreactor was able to achieve $E$. coli cell density of $190 \mathrm{~g} \mathrm{~L}^{-1}$. Fuchs et al. ${ }^{66}$ argued that a single vessel is not very viable due to sterilization difficulties, as well as sensitivity to mechanical stress during stirring and oxygen transfer limitations. Using an external membrane module, Fuchs et al. ${ }^{66}$ demonstrated that the lab-scale dialysis reactor cultivation of $E$. coli could be replicated on an industrial scale. A 300-L reactor using this external membrane dialysis technique was able to achieve cell densities like those in conventional fed-batch $\left(190 \mathrm{~g} \mathrm{~L}^{-1}\right)$, resulting in a 3.8 -fold increase in the production of protein.

\section{Pressurized reactor}

Since oxygen transfer can be critical in HDC, methods to improve the efficiency of oxygen transfer can be lucrative for the cultivation process. High-density cultivation of $E$. coli revealed that pressurized reactors can be a method to meet the high demand of oxygen ${ }^{67}$. Gas flow rate management along with increases in pressure allowed for mitigation of the carbon dioxide inhibition that developed, allowing for a final cell density of $130 \mathrm{~g} \mathrm{~L}^{-1}$, with the increased tryptophan synthase specific activity of $160 \mathrm{U} \mathrm{mg}^{-1}$-protein which was 40-fold higher than obtained with non-recombinant $E$. coli cells.

\section{Control and operating parameters}

There are four basic approaches to implementing the feeding schedules:

1. The open-loop control scheme.

2. Indirect control of substrate based on the non-feed parameter.

3. Indirect control based on mass balance equations.

4. Direct control based on on-line substrate measurements.

Measurements can be done off-line, semi-online or online. On-line measurements offer better and more flexible control of the feeding. The operation of the reactor is strongly influenced by the measurement possibilities and the mathematic model of the process ${ }^{68,69}$. The type and quality of sensors available is a major consideration for the determination of the control scheme.

Open-loop process control can be used when robust mathematical models for the process are available. However, it suffers from not being able to respond to any unexpected conditions during a fermentation process. An indirect feedback control utilizes an observable parameter that is closely related to the course of microbial fermentation, such as dissolved oxygen, $\mathrm{pH}$, carbon dioxide partial pressure, or culture fluorescence. These readings can be used as an indication of the state of the fermentation process. The direct feedback control is the most accurate of the control schemes. It uses the concentration of the limiting substrate in the culture medium as the parameter. However, there is much difficulty in its use, since obtaining accurate on-line substrate measurements can be complicated by the scarcity of sensors that can measure many compounds. However, in the cases where it is utilized, it provides a controlled process, that can respond very well to unexpected conditions $\mathrm{s}^{70,71}$.

The green fluorescent protein (GFP) was used as a model protein to study the recombinant protein production by the strain Methylobacterium extorquens ATCC 55366 by Béland et al. ${ }^{72}$ Scale-up from shake flasks to 20-L fed-batch fermentation was achieved with methanol as a sole carbon and energy source in a minimal medium. The methanol concentration was monitored with an on-line semiconductor gas sensor in the culture broth. It was maintained at a non-toxic level of $1.4 \mathrm{~g} \mathrm{~L}^{-1}$ with an adaptive control which regulated the methanol feed rate. A maximum growth rate of $0.18 \mathrm{~h}^{-1}$ with an overall cell yield of $0.3 \mathrm{~g} \mathrm{~g}^{-1}$ methanol was achieved, producing GFP that accounted for $16 \%$ of cell protein content.

Similarly, Bourque et al. ${ }^{73}$ revealed that Methylobacterium extorquens ATCC 55366 can be successfully cultivated at very high cell densities in a fed-batch fermentation system using methanol as a sole carbon and energy source in a minimal medium to produce poly b-hydroxybutyrate (PHB). Cell biomass levels were between $100 \mathrm{~g} \mathrm{~L}^{-1}$ and $115 \mathrm{~g} \mathrm{~L}^{-1}$ (dry weight) and cells contained between $40 \%$ and $46 \%$ PHB on a dry-weight basis. Controlling the methanol concentration at a very low level (less than $0.01 \mathrm{~g} \mathrm{~L}^{-1}$ ) during the PHB production phase, led not only to prevention of oxygen limitation but also to the production of very high-molecular-mass PHB, in the 900-1800 kDa range.

When investigating the enhancement of Candida rugosa lipase production using different control fed-batch operational strategies, Gordillo et al. ${ }^{21}$ compared constant substrate feeding rate strategy with feeding-rate control based on a constant specific growth rate and found that maximum lipase 
production by Candida rugosa with a constant specific growth rate strategy was twice that using a constant substrate feeding rate. The isozymes produced using constant specific growth rate strategy were three to four times more active compared to those with constant feeding rate strategy. On-line carbon dioxide evolution rates (CER) were used to evaluate cell specific growth rates using a mathematical model based on continuous culture studies.

Feedback control can also be implemented to dual-level systems to obtain finer control action. In the case of a fed-batch culture of recombinant $E$. coli, Turner et ll $^{74}$ found that higher cell concentrations with limited by-product formation can be achieved by using a two-level control scheme that measured galactose (carbon substrate) and acetate (by-product) concentrations and adjusting feed rates accordingly.

The parameters such as $\mathrm{pH}$, temperature, and dissolved oxygen affect the cell growth and product formation, which needs to be controlled at optimum values. The control parameters may also be switched based on the reactor conditions and specific to process as different parameters need to be controlled at different stages of bioprocesses. In the case of high-density cultivation of baker's yeast, the substrate concentration needs to be controlled during the initial stages of fermentation to avoid formation of by-products, but oxygen transfer becomes limiting at the later stage of fermentation upon reaching the high cell density, and dissolved oxygen is the one that needs to be controlled ${ }^{75}$. The choice of parameters is dependent on the system, and decisions are frequently made based on convenience and prior experimental observations. Mathematical models can be used to estimate the quality of the controlling variables and combined with the availability of sensors; the reactor operation can be dictated.

\section{Calorimetry}

Calorimetry is a basic control tool that can be used in an indirect control scheme. It involves measurement of heat produced during the microbial growth process. It is an easily performed continuous on-line measurement that can be done without disturbing the culture. Its main advantage lies in the generality since all microbial processes generally produce heat. It can be replaced by exhaust gas analysis unless the process is anaerobic without gaseous product formation. Larsson et al. ${ }^{76}$ described how to use the heat production rate, measured by a flow-through microcalorimeter as the only continuous on-line measurement, in order to indirectly measure the substrate and product concentrations during aerobic fed-batch growth of $S$. cerevisiae; use of this measurement reduced the maximum ethanol concentration from $2 \mathrm{~g} \mathrm{~L}^{-1}$ during batch growth to $0.2 \mathrm{~g} \mathrm{~L}^{-1}$ using the same amount of glucose $\left(5 \mathrm{~g} \mathrm{~L}^{-1}\right)$.

$\mathrm{pH}$

$\mathrm{pH}$ is a commonly used control parameter that can be used to measure the acid production by growing cells. De Swaaf et al. ${ }^{77}$ used both a constant glucose concentration feeding strategy with Crypthecodinium cohnii to produce docosahexaenoic acid, as well as an acetic acid feeding strategy that was controlled by culture $\mathrm{pH}$. A feed consisting of acetic acid $(50 \% \mathrm{w} / \mathrm{w})$ resulted in a higher overall volumetric productivity of DHA (rDHA) than a feed consisting of $50 \%(\mathrm{w} / \mathrm{v})$ glucose (38 and 14 $\mathrm{mg} \mathrm{L} \mathrm{L}^{-1} \mathrm{~h}^{-1}$, respectively). The rDHA productivity was further increased to $48 \mathrm{mg} \mathrm{L}^{-1} \mathrm{~h}^{-1}$ using a feed consisting of pure acetic acid. The latter fermentation strategy resulted in final concentrations of 109 $\mathrm{g} \mathrm{L}^{-1}$ dry biomass, $61 \mathrm{~g} \mathrm{~L}^{-1}$ lipid, and $19 \mathrm{~g} \mathrm{~L}^{-1}$ DHA, which were some of the highest values reported for a heterotrophic alga.

Files et al. ${ }^{20}$ showed the contrasting effects that $\mathrm{pH}$ can have on the cultivation process. A Pichia pastoris fermentation process for producing high levels of recombinant human cystatin-C was investigated at multiple $\mathrm{pH}$ conditions, and it was found that, although cell density increased as $\mathrm{pH}$ increased, active cystatin-C yields dropped. Thus, it is important to consider the conflicting results of the variable to optimize the culture. The results of the fermentation of Pichia pastoris are of great importance because Pichia strains are used very often for recombinant protein production in biotechnological processes $^{78}$.

Chen et al. ${ }^{79}$ showed how rhamnolipid production by Pseudomonas aeruginosa S2 can be enhanced, in addition to increased cell concentrations, by the $\mathrm{pH}$ stat control of feeding, as opposed to constant feeding. Batch fermentation using optimal medium and operating conditions resulted in rhamnolipid production of $5.31 \mathrm{~g} \mathrm{~L}^{-1}$ by $P$. aeruginosa $\mathrm{S} 2$ in a glucose-based medium. Constant feeding of glucose increased that maximum rhamnolipid concentration to $6.06 \mathrm{~g} \mathrm{~L}^{-1}$ with $6 \%$ glucose feed. Combining a repeated fed-batch culture with the $\mathrm{pH}$-stat led to a marked increase in the rhamnolipid production, resulting in a yield of $9.4 \mathrm{~g} \mathrm{~L}^{-1}$.

During the fermentation of lactic acid bacteria, large amounts of acids are produced which result in an inhibition of microbial growth after reaching a certain concentration. With the use of adaptive laboratory evolution, genome shuffling, and synthetic biology, new strains have been created with improved acid resistance to withstand low $\mathrm{pH}$ values and thus ability to achieve higher cell concentra- 
tions $^{80}$. Increased acid tolerance of Lactobacillus casei resulted in $60 \%, 13.6 \%$, and $65.6 \%$ increases in concentrations of biomass, lactate and acetate, respectively, when cultured at $\mathrm{pH} 4.3$ for $64 \mathrm{~h}^{81}$.

\section{Respiratory quotient}

Respiratory Quotient (RQ) is the ratio of carbon dioxide production rate and oxygen consumption rates in a bioreactor, which can be measured online rapidly using gas analyses. This dimensionless number is a measure of basal metabolic rate in the broth and it is a form of indirect calorimetry. Jong et al. ${ }^{82}$ used RQ as control parameter to manage glucose concentrations and enhance production of thuringiensin by Bacillus thuringiensis in a modified airlift reactor. While batch culture with similar glucose conditions achieved a maximum of $1.7 \mathrm{~g} \mathrm{~L}^{-1}$ thuringiensin production with $6 \cdot 10^{12}$ cells per $\mathrm{L}$, the fed-batch operation with glucose concentration controlled by the RQ method at $3 \mathrm{~g} \mathrm{~L}^{-1}$ achieved thuringiensin concentrations of $11.71 \mathrm{~g} \mathrm{~L}^{-1}$ and $4 \cdot 10^{13}$ cells per $\mathrm{L}$ with a yield of $0.0905 \mathrm{~g}$ thuringiensin $\mathrm{g}^{-1}$ glucose. This is a significant improvement over the batch culture.

Ikeda et al. ${ }^{83}$ also used a RQ-dependent feedback regulation to avoid glucose effect from overfeeding in the production of Recombinant Human Lysosomal Acid Lipase in Schizosaccharomyces pombe in high-density cultivation. The nutrient supply was automatically initiated and controlled based on changes in respiratory quotient as glucose in broth was consumed in batch-phase culture achieving $>50 \mathrm{~g} \mathrm{~L}^{-1}$ of dry cell weight $\mathrm{L}^{-1}$ and human lysosomal lipase activity of $16000 \mathrm{U} \mathrm{L}^{-1}$.

\section{Dissolved oxygen}

Many bioprocesses are aerobic requiring above-critical levels of dissolved oxygen in the broth. This is the major limiting factor in HDC due to the low solubility of oxygen in the culture liquids. At standard temperature and pressure (STP 25 ${ }^{\circ} \mathrm{C}$, and 1 atm), the saturation dissolved oxygen concentration in medium sparged with atmospheric air is around $8 \mathrm{mg} \mathrm{L}^{-1}$. Although the oxygen supply can be increased by changing the aeration rate and agitation speed $^{55}$, given the reactor design including impeller type and dimensions, oxygen can still become limiting in HDC. Dissolved oxygen concentrations below critical levels result in reduced specific growth rates, shifting metabolism, and formation of several unwanted metabolites arising from mixed acid metabolism, such as acetate, lactate, and ethanol ${ }^{84,82}$. This issue may be mitigated by use of enriched (even pure) oxygen and/or pressurizing the reactors. Since the dissolved oxygen concentration at saturation is proportional to the partial pressure of oxygen (Henry's Law), both the methods result in increased oxygen supply to the cells.

Belem and $\mathrm{Lee}^{85}$ investigated oligonucleotide production in fed-batch fermentation of cheese whey with Kluyveromyces marxianus during high-density cultivation. While yields and specific growth rates in batch operation were higher than in fed-batch operation, productivities were higher during in fed-batch reactor, especially when the aeration rate was increased to $2 \mathrm{vvm}$.

Adamitsch et al. ${ }^{86}$ used oxygen-enriched air supply to achieve increased oxygen transfer. By the addition of pure oxygen supplement to the air inlet, a minimum of $20 \%$ dissolved $\mathrm{O}_{2}$ saturation was maintained. This allowed the cultivation of Brevibacterium linens to cell density reaching $50 \mathrm{~g} \mathrm{~L}^{-1}$ in $60 \mathrm{~h}$, with the volumetric productivity of the proteolytic and lipolytic activities $4220 \mathrm{U} \mathrm{L}^{-1} \mathrm{~h}^{-1}$ and $7.3 \mathrm{U} \mathrm{L}^{-1} \mathrm{~h}^{-1}$, respectively. The overall enzyme yield coefficient on biomass had not attained the level of $18.7 \cdot 10^{3} \mathrm{U} \mathrm{g} \mathrm{g}^{-1}$, which was determined in a batch cultivation yielding $1.9 \mathrm{~g} \mathrm{~L}^{-1}$ bacterial biomass, but the volumetric productivity in high-cell-density culture $\left(4.2 \cdot 10^{3} \mathrm{U} \mathrm{L}^{-1} \mathrm{~h}^{-1}\right.$ at $\left.55 \mathrm{~h}\right)$ exceeded considerably that of the volumetric productivity of a batch fermentation $\left(1.8 \cdot 10^{3} \mathrm{U} \mathrm{L}^{-1} \mathrm{~h}^{-1}\right)$.

Park et $a l .{ }^{87}$ utilized a strategy of supplying high-purity oxygen to increase the viable cell density in a bioreactor and enhance the production of the target protein in the production of human serum albumin by the fed-batch culture of Hansenula polymorpha. To supply high-purity oxygen to the bioreactor, nearly $100 \%$ high-purity oxygen from a commercial bomb or higher than $93 \%$ oxygen available in situ from a pressure swing adsorption (PSA) oxygen generator was employed. With highpurity oxygen, the final $H$. polymorpha cell densities and the HSA concentrations were $24.6 \mathrm{~g} \mathrm{~L}^{-1}$ and $5.1 \mathrm{~g} \mathrm{~L}^{-1}$ in the 5-L fermenter, and $24.8 \mathrm{~g} \mathrm{~L}^{-1}$ and $4.5 \mathrm{~g} \mathrm{~L}^{-1}$ in the $30-\mathrm{L}$ fermenter, respectively. These were 2-10 times higher than those obtained in airsparged fed-batch fermentations.

\section{Dissolved carbon dioxide}

Carbon dioxide is the final product of the breakdown of carbon sources utilized for energy purposes. HDC increases carbon dioxide production rates, and thus potential for high dissolved carbon dioxide concentrations. While the carbon dioxide is by itself inhibitory to cell growth ${ }^{55}$, it also results in the production of acetate and carbonate, which can result in acidification of the medium. Castan et al. ${ }^{84}$ reported the toxic effects of carbon dioxide resulting in growth inhibition. As a gas, carbon dioxide also follows Henry's Law regarding partial pressures and dissolved concentration. This results in a 
dilemma on the use of the pressurized reactor, which in addition to increasing the oxygen supply, may also enhance the effects of carbon dioxide ${ }^{67}$. But there are also positive effects of carbon dioxide on microbial growth and product formation ${ }^{88,89}$. These examples of the positive and negative effects of $\mathrm{CO}_{2}$ indicate the importance of the consideration of $\mathrm{CO}_{2}$ concentrations in bioreactors.

Chiu et al. ${ }^{90}$ investigated carbon dioxide sequestration in photobioreactors growing high-density cultures of microalgae. Three types of photobioreactors were tested: (i) without inner column (i.e., a bubble column), (ii) with a centric-tube column, and (iii) with a porous centric-tube column. The porous centric tube column had the highest specific growth rate for Chlorella sp. NCTU2. Their results showed that the $\mathrm{CO}_{2}$ removal efficiency was related to biomass concentration and aeration rate.

\section{Agitation}

A consequence of the high viscosity exhibited by HDC is difficulty in mixing the content of the bioreactor, which increases with increasing reactor $\mathrm{size}^{27}$. As a result, large-scale reactors have gradients of concentrations due to incomplete mixing. This can result in cells experiencing toxic concentrations of substrate in certain zones, while others may be nutrient-starved. Furthermore, even when the cells do circulate through these zones, they may experience stress as a result of the varying environmental conditions. Kapat et al. ${ }^{91}$ suggested that increasing the rate of agitation can lessen these issues, enhancing oxygen transfer coefficient and increasing protein production. However, the application of this technique may be limited to those cell types that can withstand the shear stress generated due to the increased agitation, while other cell types may undergo lysis as a result ${ }^{92}$. Also, foam formation is intensified with increased agitation speeds. Increasing cell and product concentrations also enhance foam production. Since excessive foaming can interfere with normal operation of aerated stirred reactors, foam reduction measures must be considered when designing the bioreactor for HDC.

$\mathrm{Vu}$ and $\mathrm{Kim}^{93}$ investigated HDC fed-batch culture of Saccharomyces cerevisiae KV-25 using molasses and corn steep liquor. The Saccharomyces cerevisiae $\mathrm{KV}-25$ cell mass was significantly dependent on the ratio between $\mathrm{C}$ and $\mathrm{N}$ sources. In the fed-batch culture, the feed phase was preceded by a batch phase using the optimized medium, and a very high dried-cell-mass yield of $187.63 \mathrm{~g} \mathrm{~L}^{-1}$ was successfully attained by feeding a mixture of $20 \%$ $(\mathrm{v} / \mathrm{v})$ molasses and $80 \%(\mathrm{v} / \mathrm{v})$ CSL at a rate of 22 $\mathrm{mL} \mathrm{h}^{-1}$. In this system, the production of cell mass depended mainly on the agitation speed, the compo- sition of the feed medium, and the glucose level in the medium, but only slightly on the aeration rate.

\section{Cellular stress}

Even if the feeding profile of required substrates and oxygen supply are optimized, HDC results in cellular stress of the proliferated microorganisms. Singh et al. ${ }^{94}$ investigated the cellular stress during different feeding rates in an E. coli fermentation process by transcriptome analysis. They found the production of heat shock proteins to be strongly upregulated. Simultaneously, the uptake of substrates was affected by the feeding rate and the followed growth rate $(\mu)$ by a regulation of the responsible gene expression. Also, the genes for the enzymes of the tricarboxylic acid cycle were strongly affected by the feeding rate. These insights in the metabolic functions are very helpful tools to overcome metabolic bottlenecks and improve feeding strategies for enhanced productivity and product quality during HDC processes.

\section{Outlook}

Even though HDCs have been developed and optimized over several years, there is still a strong need for further optimization and research in this field to help biotechnological products compete with mineral oil-based production processes, and to achieve a bio-based economy. New techniques as $3 \mathrm{D}$-printing ${ }^{95}$ may help to improve existing fermentation processes (immobilization) and develop new ones. Further research is required to overcome the existing problems associated with gradients of temperature, $\mathrm{pH}$, and substrate concentration in largescale bioreactors. New developments in fermentation technology may help to achieve additional knowledge about the microbial and biochemical processes.

\section{References}

1. Gao, D., Wang, S., Li, H., Yu, H., Qi, Q., Identification of a heterologous cellulase and its N-terminus that can guide recombinant proteins out of Escherichia coli, Microb. Cell Fact. 14 (2015) 49. doi: https://doi.org/10.1186/s12934-015-0230-8

2. Lippi, L., Bähr, L., Wüstenberg, A., Wilde, A., Steuer, R., Exploring the potential of high-density cultivation of cyanobacteria for the production of cyanophycin, Algal Res. 31 (2018) 363. doi: https://doi.org/10.1016/j.algal.2018.02.028

3. Faust, G., Janzen, N. H., Bendig, C., Romer, L., Kaufmann, $K$., Weuster-Botz, D., Feeding strategies enhance high cell density cultivation and protein expression in milliliter scale bioreactors, Biotechnol J. 9 (2014) 1293.

doi: https://doi.org/10.1002/biot.201400346 
4. Shojaosadati, S. A., Varedi Kolaei, S. M., Babaeipour, V. Farnoud, A. M., Recent advances in high cell density cultivation for production of recombinant protein, Iran J. Biotechnol. 6 (2008) 63

5. Brown, S. H., Bashkirova, L., Berka, R., Chandler, T., Doty, T., McCall, K., McCulloch, M., McFarland, S., Thompson, S., Yaver, D., Berry, A., Metabolic engineering of Aspergillus oryzae NRRL 3488 for increased production of L-malic acid, Appl. Microbiol. Biotechnol. 97 (2013) 8903. doi: https://doi.org/10.1007/s00253-013-5132-2

6. Liu, J., Xie, Z., Shin, H.-D., Li, J., Du, G., Chen, J., Liu, L., Rewiring the reductive tricarboxylic acid pathway and L-malate transport pathway of Aspergillus oryzae for overproduction of L-malate, J. Biotechnol. 253 (2017) 1. doi: https://doi.org/10.1016/j.jbiotec.2017.05.011

7. Mesgari-Shadi, A., Sarrafzadeh, M. H., Osmotic conditions could promote scFv antibody production in the Escherichia coli HB2151, BI. 7 (2017) 199. doi: https://doi.org/10.15171/bi.2017.23

8. Tapia, F., Vázquez-Ramírez, D., Genzel, Y., Reichl, U., Bioreactors for high cell density and continuous multi-stage cultivations: Options for process intensification in cell culture-based viral vaccine production, Appl. Microbiol. Biotechnol. 100 (2016) 2121. doi: https://doi.org/10.1007/s00253-015-7267-9

9. Lukondeh, T., Ashbolt, N. J., Rogers, P. L., Fed-batch fermentation for production of Kluyveromyces marxianus FII 510700 cultivated on a lactose-based medium, J. Ind. Microbiol. Biotechnol. 32 (2005) 284. doi: https://doi.org/10.1007/s10295-005-0245-y

10. Belanger, L., Figueira, M. M., Bourque, D., Morel, L., Beland, M., Laramee, L., Groleau, D., Miguez, C. B., Production of heterologous protein by Methylobacterium extorquens in high cell density fermentation, FEMS Microbiol. Lett. 231 (2004) 197. doi: https://doi.org/10.1016/S0378-1097(03)00956-X

11. Heyland, J., Fu, J., Blank, L. M., Schmid, A., Quantitative physiology of Pichia pastoris during glucose-limited highcell density fed-batch cultivation for recombinant protein production, Biotechnol. Bioeng. 107 (2010) 357. doi: https://doi.org/10.1002/bit.22836

12. Kim, M., Cho, K. S., Ryu, H. W., Lee, E. G., Chang, Y. K., Recovery of poly(3-hydroxybutyrate) from high cell density culture of Ralstonia eutropha by direct addition of sodium dodecyl sulfate, Biotechnol. Lett. 25 (2003) 55. doi: https://doi.org/10.1023/A:1021734216612

13. Choi, J. H., Keum, K. C., Lee, S. Y., Production of recombinant proteins by high cell density culture of Escherichia coli, Chem. Eng. Sci. 61 (2006) 876 doi: https://doi.org/10.1016/j.ces.2005.03.031

14. Shiloach, J., Fass, R., Growing E. coli to high cell density - A historical perspective on method development, Biotechnol. Adv. 23 (2005) 345. doi: https://doi.org/10.1016/j.biotechadv.2005.04.004

15. Choi, J. H., Keum, K. C., Lee, S. Y., Production of recombinant proteins by high cell density culture of Escherichia coli, Chem. Eng. Sci. 61 (2006) 876. doi: https://doi.org/10.1016/j.ces.2005.03.031

16. Ukkonen, K., Neubauer, A., Pereira, V. J., Vasala, A., High Yield of Recombinant Protein in Shaken E. coli Cultures with Enzymatic Glucose Release Medium EnPresso B. In Burgess-Brown, N. A., (Ed.), Heterologous Gene Expression in E. coli: Methods and Protocols, Humana Press, New York, 2017, pp 127-137. doi: https://doi.org/10.1007/978-1-4939-6887-9 8
17. Glazyrina, J., Materne, E. M., Dreher, T., Storm, D., Junne, S., Adams, T., Greller, G., Neubauer, P., High cell density cultivation and recombinant protein production with Escherichia coli in a rocking-motion-type bioreactor, Microb. Cell Fact. 9 (2010) 42. doi: https://doi.org/10.1186/1475-2859-9-42

18. Kulpreecha, S., Boonruangthavorn, A., Meksiriporn, B., Thongchul, $N$., Inexpensive fed-batch cultivation for high poly(3-hydroxybutyrate) production by a new isolate of $\mathrm{Ba}$ cillus megaterium, J. Biosci. Bioeng. 107 (2009) 240. doi: https://doi.org/10.1016/j.jbiosc.2008.10.006

19. Kurosawa, K., Boccazzi, P., de Almeida, N. M., Sinskey, A. $J$., High-cell-density batch fermentation of Rhodococcus opacus PD630 using a high glucose concentration for triacylglycerol production, J. Biotechnol. 147 (2010) 212. doi: https://doi.org/10.1016/j.jbiotec.2010.04.003

20. Files, D., Ogawa, M., Scaman, C. H., Baldwin, S. A., A Pichia pastoris fermentation process for producing high-levels of recombinant human cystatin-C, Enzyme Microb. Technol. 29 (2001) 335. doi: https://doi.org/10.1016/S0141-0229(01)00395-7

21. Gordillo, M. A., Sanz, A., Sanchez, A., Valero, F., Montesinos, J. L., Lafuente, J., Sola, C., Enhancement of Candida rugosa lipase production by using different control fedbatch operational strategies, Biotechnol. Bioeng. 60 (1998) 156.

doi: https://doi.org/10.1002/(SICI)1097-0290(19981020)60:2 $<156:$ :AID-BIT3>3.0.CO;2-M

22. Wen, Z. Y., Chen, F., Perfusion culture of the diatom Nitzschia laevis for ultra-high yield of eicosapentaenoic acid, Process Biochem. 38 (2002) 523. doi: https://doi.org/10.1016/S0032-9592(02)00174-7

23. Egloff, S., Tschudi, F., Schmautz, Z., Refardt, D., High-density cultivation of microalgae continuously fed with unfiltered water from a recirculating aquaculture system, Algal Res. 34 (2018) 68. doi: https://doi.org/10.1016/j.algal.2018.07.004

24. Dogaris, I., Welch, M., Meiser, A., Walmsley, L., Philippidis, G., A novel horizontal photobioreactor for high-density cultivation of microalgae, Bioresour. Technol. 198 (2015) 316 .

doi: https://doi.org/10.1016/j.biortech.2015.09.030

25. Wang, W., Zhang, Z. Y., Zhong, J. J., Enhancement of ginsenoside biosynthesis in high-density cultivation of Panax notoginseng cells by various strategies of methyl jasmonate elicitation, Appl. Microbiol. Biotechnol. 67 (2005) 752. doi: https://doi.org/10.1007/s00253-004-1831-z

26. Zhang, Q., Wu, D., Lin, Y., Wang, X., Kong, H., Tanaka, S., Substrate and product inhibition on yeast performance in ethanol fermentation, Energy Fuels 29 (2015) 1019. doi: https://doi.org/10.1021/ef502349v

27. Lee, S. Y., High cell-density culture of Escherichia coli, Trends Biotechnol. 14 (1996) 98. doi: https://doi.org/10.1016/0167-7799(96)80930-9

28. Matsui, T., Shinzato, N., Yokota, H., Takahashi, J., Sato, S., High cell density cultivation of recombinant $E$. coli with a pressurized culture, Process Biochem. 41 (2006) 920. doi: https://doi.org/10.1016/j.procbio.2005.10.004

29. de Maré, L., Velut, S., Ledung, E., Cimander, C., Norrman, B., Karlsson, E. N., Holst, O., Hagander, P., A cultivation technique for $E$. coli fed-batch cultivations operating close to the maximum oxygen transfer capacity of the reactor, Biotechnol. Lett. 27 (2005) 983. doi: https://doi.org/10.1007/s10529-005-7844-6 
30. Donovan, R. S., Robinson, C. W., Glick, B. R., Review: Optimizing inducer and culture conditions for expression of foreign proteins under the control of the lac promoter, J. Ind. Microbiol. 16 (1996) 145. doi: https://doi.org/10.1007/BF01569997

31. Subramaniam, R., Thirumal, V., Bajpai, R., Chistoserdov, A., Esser, M., Bader, J., Popovic, M., In Characterization of fermentation products from high density cultivation of $\mathrm{Li}$ pomyces starkeyi, WCCE10, Barcelona, Spain, 2017.

32. Thirumal, V., Chistoserdov, A., Bajpai, R., Bader, J., Popovic, M., Subramaniam, $R$., Effect of developed low cost minimal medium on lipid and exopolysaccharide production by Lipomyces starkeyi under repeated fed-batch and continuous cultivation, Chem. Biochem. Eng. Q. 2019 (Accepted for publication).

33. Riesenberg, D., Guthke, R., High-cell-density cultivation of microorganisms, Appl. Microbiol. Biotechnol. 51 (1999) 422. doi: https://doi.org/10.1007/s002530051412

34. Krause, M., Ukkonen, K., Haataja, T., Ruottinen, M., Glumoff, T., Neubauer, A., Neubauer, P., Vasala, A., A novel fed-batch based cultivation method provides high cell-density and improves yield of soluble recombinant proteins in shaken cultures, Microb. Cell Fact. 9 (2010) 11. doi: https://doi.org/10.1186/1475-2859-9-11

35. Pim, V. H., Erik, D. H., Johannes P., van, D., Jack, T. P., Fermentative capacity in high cell density fed-batch cultures of baker's yeast, Biotechnol. Bioeng. 68 (2000) 517. doi: https://doi.org/10.1002/(SICI)1097-0290(20000605)68:5 $<517::$ AID-BIT5>3.0.CO;2-O

36. Satoru, M., Hironori, M., Shoichi, S., Kenji, S., Takeshi, K., Effect of amino acid supplement on cell yield and gene product in Escherichia coli harboring plasmid, Biotechnol. Bioeng. 28 (1986) 204

doi: https://doi.org/10.1002/bit.260280209

37. Görgens, J. F., van Zyl, W. H., Knoetze, J. H., Hahn-Hägerdal, B., Amino acid supplementation improves heterologous protein production by Saccharomyces cerevisiae in defined medium, Appl. Microbiol. Biotechnol. 67 (2005) 684. doi: https://doi.org/10.1007/s00253-004-1803-3

38. Beckmann, B., Hohmann, D., Eickmeyer, M., Bolz, S. Brodhagen, C., Derr, P., Sanders, E. A., An improved high cell density cultivation-iHCDC - strategy for leucine auxotrophic Escherichia coli K12 ER2507, Eng. Life Sci. 17 (2017) 857. doi: https://doi.org/10.1002/elsc.201700054

39. Lau, J., Tran, C., Licari, P., Galazzo, J., Development of a high cell-density fed-batch bioprocess for the heterologous production of 6-deoxyerythronolide B in Escherichia coli, J. Biotechnol. 110 (2004) 95. doi: https://doi.org/10.1016/j.jbiotec.2004.02.001

40. Burgard, J., Valli, M., Graf, A. B., Gasser, B., Mattanovich, $D$., Biomarkers allow detection of nutrient limitations and respective supplementation for elimination in Pichia pastoris fed-batch cultures, Microb. Cell Fact. 16 (2017) 117. doi: https://doi.org/10.1186/s12934-017-0730-9

41. Cereghino, G. P. L., Cereghino, J. L., Ilgen, C., Cregg, J. $M$., Production of recombinant proteins in fermenter cultures of the yeast Pichia pastoris, Curr. Opin. Biotechnol. 13 (2002) 329. doi: https://doi.org/10.1016/S0958-1669(02)00330-0

42. Winzer, K., Hardie, K. R., Williams, P., Bacterial cell-to-cell communication: Sorry, can't talk now — gone to lunch!, Curr. Opin. Microbiol. 5 (2002) 216. doi: https://doi.org/10.1016/S1369-5274(02)00304-1
43. Brady, C. P., Shimp, R. L., Miles, A. P., Whitmore, M., Stowers, A. W. High-level production and purification of P30P2MSP119, an important vaccine antigen for malaria, expressed in the methylotropic yeast Pichia pastoris, Protein Expr. Purif. 23 (2001) 468. doi: https://doi.org/10.1006/prep.2001.1526

44. Yup, L. S., Ho, W. H., Jong-il, C., Hwan, L. S., Cheol, L. S., Soo, H. C., Production of medium chain length polyhydroxyalkanoates by high cell density cultivation of Pseudomonas putida under phosphorus limitation, Biotechnol. Bioeng. 68 (2000) 466. doi: https://doi.org/10.1002/(SICI)1097-0290(20000520)68:4 $<466:: A I D-B I T 12>3.0 . C O ; 2-T$

45. López, N. I., Pettinari, M. J., Stackebrandt, E., Tribelli, P. M., Põtter, M., Steinbüchel, A., Méndez, B. S., Pseudomonas extremaustralis $s p$. nov., a poly(3-hydroxybutyrate) producer isolated from an antarctic environment, Curr. Microbiol. 59 (2009) 514. doi: https://doi.org/10.1007/s00284-009-9469-9

46. Kim, B. S., Lee, S. C., Lee, S. Y., Chang, H. N., Chang, Y. K., Woo, S. I., Production of poly(3-hydroxybutyric acid) by fed-batch culture of Alcaligenes eutrophus with glucose concentration control, Biotechnol. Bioeng. 43 (1994) 892. doi: https://doi.org/10.1002/bit.260430908

47. Riedel, S. L., Bader, J., Brigham, C. J., Budde, C. F., Yusof, Z. A. M., Rha, C., Sinskey, A. J., Production of poly(3-hydroxybutyrate-co-3-hydroxyhexanoate) by Ralstonia eutropha in high cell density palm oil fermentations, Biotechnol. Bioeng. 109 (2012) 74. doi: https://doi.org/10.1002/bit.23283

48. Subramaniam, R., Rahman, S. M., Dufreche, S., Bajpai, R., Zappi, M. E., In Production of microbial lipids from sweet potato starch using Lipomyces starkeyi, AIChE, San Francisco, CA., 2013.

49. Subramaniam, R., Dufreche, S., Bajpai, R., Zappi, M. E., In Strategy development for cost effective lipid production from starchy waste, AIChE, Pittsburgh, PA., 2012.

50. Rahman, S., Arbter, P., Popovic, M., Bajpai, R., Subramani$a m, R$., Microbial lipid production from lignocellulosic hydrolyzates: Effect of carbohydrate mixtures and acid-hydrolysis byproducts on cell growth and lipid production by Lipomyces starkeyi, J. Chem. Technol. Biotechnol. 92 (2017) 1980. doi: https://doi.org/10.1002/jctb.5185

51. Castrillo, J. I., Kaliterna, J., Weusthuis, R. A., van Dijken, J. P., Pronk, J. T., High-cell-density cultivation of yeasts on disaccharides in oxygen-limited batch cultures, Biotechnol. Bioeng. 49 (1996) 621. doi: https://doi.org/10.1002/(SICI)1097-0290(19960320)49:6 $<621::$ AID-BIT3>3.0.CO;2-Q

52. Jensen, E. B., Carlsen, S., Production of recombinant human growth hormone in Escherichia coli: Expression of different precursors and physiological effects of glucose, acetate, and salts, Biotechnol. Bioeng. 36 (1990) 1. doi: https://doi.org/10.1002/bit.260360102

53. Babaeipour, V., Shojaosadati, S. A., Robatjazi, S. M., Khalilzadeh, R., Maghsoudi, N., Over-production of human interferon- $\gamma$ by HCDC of recombinant Escherichia coli, Process Biochem. 42 (2007) 112. doi: https://doi.org/10.1016/j.procbio.2006.07.009

54. Khalilzadeh, R., Shojaosadati, S. A., Maghsoudi, N., Mohammadian-Mosaabadi, J., Mohammadi, M. R., Bahrami, A., Maleksabet, N., Nassiri-Khalilli, M. A., Ebrahimi, M., Naderimanesh, $H$., Process development for production of recombinant human interferon-gamma expressed in Escherichia coli, J. Ind. Microbiol. Biotechnol. 31 (2004) 63. doi: https://doi.org/10.1007/s10295-004-0117-x 
55. Lee, S. Y., High cell-density culture of Escherichia coli, Trends Biotechnol. 14 (1996) 98. doi: https://doi.org/10.1016/0167-7799(96)80930-9

56. Kim, B. S., Hou, C. T., Production of lipase by high cell density fed-batch culture of Candida cylindracea, Bioprocess Biosyst. Eng. 29 (2006) 59. doi: https://doi.org/10.1007/s00449-006-0058-z

57. Fickers, P., Destain, J., Thonart, P., Improvement of Yarrowia lipolytica lipase production by fed-batch fermentation, J. Basic Microbiol. 49 (2009) 212.

doi: https://doi.org/10.1002/jobm.200800186

58. Joo-Hyung, H., Kyoung, H. W., Young, C. E., Woong, K. M., Jeong-Yoon, K., Ho, K. C., Ki, R. S., Ah, K. H., Properties of the Hansenula polymorpha-derived constitutive GAP promoter, assessed using an HSA reporter gene, FEMS Yeast Res. 4 (2003) 175. doi: https://doi.org/10.1016/S1567-1356(03)00150-8

59. Choi, H.-K., Kim, S.-I., Son, J.-S., Hong, S.-S., Lee, H.-S. Chung, I.-S., Lee, H.-J., Intermittent maltose feeding enhances paclitaxel production in suspension culture of Taxus chinensis cells, Biotechnol. Lett. 22 (2000) 1793. doi: https://doi.org/10.1023/A:1005658405449

60. Shin, C. S., Hong, M. S., Bae, C. S., Lee, J., Enhanced production of human mini-proinsulin in fed-batch cultures at high cell density of Escherichia coli BL21(DE3), Biotechnol. Prog. 13 (1997) 249 doi: https://doi.org/10.1021/bp970018m

61. Brennan, Z., FDA Allows First Switch From Batch to Continuous Manufacturing for HIV Drug, US, 2016.

62. Jahic, M., Wallberg, F., Bollok, M., Garcia, P., Enfors, S. $O$., Temperature limited fed-batch technique for control of proteolysis in Pichia pastoris bioreactor cultures, Microb. Cell Fact. 2 (2003) 6. doi: https://doi.org/10.1186/1475-2859-2-6

63. Sørensen, H. P., Mortensen, K. K., Soluble expression of recombinant proteins in the cytoplasm of Escherichia coli, Microb. Cell Fact. 4 (2005) 1

doi: https://doi.org/10.1186/1475-2859-4-1

64. Wyre, C., Overton, T. W., Use of a stress-minimisation paradigm in high cell density fed-batch Escherichia coli fermentations to optimise recombinant protein production, J. Ind. Microbiol Biotechnol. 41 (2014) 1391. doi: https://doi.org/10.1007/s10295-014-1489-1

65. Nakano, K., Rischke, M., Sato, S., Markl, H., Influence of acetic acid on the growth of Escherichia coli K12 during high-cell-density cultivation in a dialysis reactor, Appl. Microbiol. Biotechnol. 48 (1997) 597.

doi: https://doi.org/10.1007/s002530051101

66. Fuchs, C., Koster, D., Wiebusch, S., Mahr, K., Eisbrenner, G., Markl, H., Scale-up of dialysis fermentation for high cell density cultivation of Escherichia coli, J. Biotechnol. 93 (2002) 243.

doi: https://doi.org/10.1016/S0168-1656(01)00402-3

67. Matsui, T., Shinzato, N., Yokota, H., Takahashi, J., Sato, S., High cell density cultivation of recombinant $E$. coli with a pressurized culture, Process Biochem. 41 (2006) 920. doi: https://doi.org/10.1016/j.procbio.2005.10.004

68. Modak, J. M., Lim, H. C., Tayeb, Y. J., General characteristics of optimal feed rate profiles for various fed-batch fermentation processes, Biotechnol Bioeng. 28 (1986) 1396. doi: https://doi.org/10.1002/bit.260280914

69. Liu, S., Chapter 17 - Bioreactor Design Operation. In Liu, S. (Ed.), Bioprocess Engineering (Second Edition), Elsevier, New York, 2017, pp 1007-1058. doi: https://doi.org/10.1016/B978-0-444-63783-3.00017-4
70. Gerson, D. F., Kole, M. M., Ozum, B., Oguztoreli, M. N., Substrate concentration control in bioreactors, Biotechnol. Genet. Eng. Rev. 6 (1988) 67. doi: https://doi.org/10.1080/02648725.1988.10647846

71. Almquist, J., Cvijovic, M., Hatzimanikatis, V., Nielsen, J., Jirstrand, M., Kinetic models in industrial biotechnology Improving cell factory performance, Metabol. Eng. 24 (2014) 38 doi: https://doi.org/10.1016/j.ymben.2014.03.007

72. Béland, M., Bourque, D., Perrier, M., Miguez, C. B., OnLine Estimation of Stoichiometric Growth Parameters for Methylobacterium extorquens, IFAC Proceed. Vol. 37 (2004) 49 doi: https://doi.org/10.1016/S1474-6670(17)32558-2

73. Bourque, D., Pomerleau, Y., Groleau, D., High-cell-density production of poly- $\beta$-hydroxybutyrate (PHB) from methanol by Methylobacterium extorquens: Production of high-molecular-mass PHB, Appl. Microbiol. Biotechnol. 44 (1995) 367. doi: https://doi.org/10.1007/BF00169931

74. Turner, C., Gregory, M. E., Turner, M. K., A study of the effect of specific growth rate and acetate on recombinant protein production of Escherichia coli JM107, Biotechnol. Lett. 16 (1994) 891 doi: https://doi.org/10.1007/BF00128620

75. Liu, S., Bioprocess Engineering: Kinetics, Biosystems, Sustainability, and Reactor Design, Elsevier, New York, 2012, pp 699-824.

76. Larsson, C., Lidh, G., Blomberg, A., Niklasson, C., Gustafsson, L., Monitoring and control of batch and fed-batch cultures of Saccharomyces cerevisiae by calorimetry, Pure Appl. Chem. 65 (1993) 1933.

77. De Swaaf, M. E., Sijtsma, L., Pronk, J. T., High-cell-density fed-batch cultivation of the docosahexaenoic acid producing marine alga Crypthecodinium cohnii, Biotechnol. Bioeng. 81 (2003) 666. doi: https://doi.org/10.1002/bit.10513

78. Yang, Z., Zhang, Z., Engineering strategies for enhanced production of protein and bio-products in Pichia pastoris: A review, Biotechnol. Adv. 36 (2018) 182. doi: https://doi.org/10.1016/j.biotechadv.2017.11.002

79. Chen, S. Y., Wei, Y. H., Chang, J. S., Repeated pH-stat fedbatch fermentation for rhamnolipid production with indigenous Pseudomonas aeruginosa S2., Appl. Microbiol. Biotechnol. 76 (2007) 67. doi: https://doi.org/10.1007/s00253-007-0980-2

80. Wang, C., Cui, Y., Ou, X., Mechanisms and improvement of acid resistance in lactic acid bacteria, Archives of microbiology 200 (2018) 195. doi: https://doi.org/10.1007/s00203-017-1446-2

81. Zhang, J., Wu, C., Du, G., Chen, J., Enhanced acid tolerance in Lactobacillus casei by adaptive evolution and compared stress response during acid stress, Biotechnol. Bioprocess Eng. 17 (2012) 283. doi: https://doi.org/10.1007/s12257-011-0346-6

82. Jong, J. Z., Hsiun, D. Y., Wu, W. T., Tzeng, Y. M., Fed-batch culture of Bacillus thuringiensis for thuringiensin production in a tower type bioreactor, Biotechnol. Bioeng. 48 (1995) 207 doi: https://doi.org/10.1002/bit.260480307

83. Ikeda, S., Nikaido, K., Araki, K., Yoshitake, A., Kumagai, $H$., Isoai, A., Production of recombinant human lysosomal acid lipase in Schizosaccharomyces pombe: Development of a fed-batch fermentation and purification process, J. Biosci. Bioeng. 98 (2004) 366. doi: https://doi.org/10.1016/S1389-1723(04)00297-X 
84. Castan, A., Näsman, A., Enfors, S.-O., Oxygen enriched air supply in Escherichia coli processes: Production of biomass and recombinant human growth hormone, Enzyme Microb. Technol. 30 (2002) 847. doi: https://doi.org/10.1016/S0141-0229(01)00490-2

85. Belem, M. A. F., Lee, B. H., Fed-batch fermentation to produce oligonucleotides from Kluyveromyces marxianus grown on whey, Process Biochem. 34 (1999) 501. doi: https://doi.org/10.1016/S0032-9592(98)00118-6

86. Adamitsch, B. F., Karner, F., Hampel, W. A., High cell density cultivation of Brevibacterium linens and formation of proteinases and lipase, Biotechnol. Lett. 25 (2003) 705. doi: https://doi.org/10.1023/A:1023402529882

87. Park, B.-S., Vladimir, A., Kim, C. H., Rhee, S.-K., Kang, H. $A$., Secretory production of Zymomonas mobilis levansucrase by the methylotrophic yeast Hansenula polymorpha, Enzyme Microb. Technol. 34 (2004) 132. doi: https://doi.org/10.1016/j.enzmictec.2003.09.005

88. Bader, J., Skelac, L., Wewetzer, S., Senz, M., Popovic, M. $K$., Bajpai, R., Effect of partial pressure of $\mathrm{CO}_{2}$ on the production of thermostable alpha-amylase and neutral protease by Bacillus caldolyticus, Prikl biokhim mikrobiol. 48 (2012) 206

89. Popović, M. K., Senz, M., Bader, J., Skelac, L., Schilf, W., Bajpai, R., Positive effect of reduced aeration rate on secretion of alpha-amylase and neutral proteases during pressurised fermentation of thermophilic Bacillus caldolyticus, N Biotechnol. 31 (2014) 141.

doi: https://doi.org/10.1016/j.nbt.2013.10.007

90. Chiu, S.-Y., Tsai, M.-T., Kao, C.-Y., Ong, S.-C., Lin, C.-S., The air-lift photobioreactors with flow patterning for high-density cultures of microalgae and carbon dioxide removal, Eng. Life Sci. 9 (2009) 254. doi: https://doi.org/10.1002/elsc.200800113

91. Kapat, A., Jung, J. K., Park, Y. H., Hong, S. Y., Choi, H. K., Effects of agitation and aeration on the production of extracellular glucose oxidase from a recombinant Saccharomyces cerevisiae, Bioprocess. Eng. 18 (1998) 347. doi: https://doi.org/10.1007/PL00008994

92. Pan, Z., Wang, H., Zhong, J., Scale-up study on suspension cultures of Taxus chinensis cells for production of taxane diterpene, Enzyme Microb. Technol. 27 (2000) 714. doi: https://doi.org/10.1016/S0141-0229(00)00276-3

93. Vu, V. H., Kim, K., High-cell-density fed-batch culture of Saccharomyces cerevisiae KV-25 using molasses and corn steep liquor, J. Microbiol. Biotechnol. 19 (2009) 1603. doi: https://doi.org/10.4014/jmb.0907.07027

94. Singh, A. B., Sharma, A. K., Mukherjee, K. J., Analyzing the metabolic stress response of recombinant Escherichia coli cultures expressing human interferon-beta in high cell density fed batch cultures using time course transcriptomic data, Mol. BioSyst. 8 (2012) 615 doi: https://doi.org/10.1039/C1MB05414G

95. Belgrano, F. D. S., Diegel, O., Pereira, N. Jr., Hatti-Kaul, $R$., Cell immobilization on 3D-printed matrices: A model study on propionic acid fermentation, Bioresour. Technol. 249 (2018) 777. doi: https://doi.org/10.1016/j.biortech.2017.10.087

96. Ibrahim, M. H., Steinbuchel, A., Poly(3-hydroxybutyrate) production from glycerol by Zobellella denitrificans MW1 via high-cell-density fed-batch fermentation and simplified solvent extraction, Appl. Environ. Microbiol. 75 (2009) 6222 . doi: https://doi.org/10.1128/AEM.01162-09

97. Shang, F., Wen, S., Wang, X., Tan, T., High-cell-density fermentation for ergosterol production by Saccharomyces cerevisiae, J. Biosci. Bioeng. 101 (2006) 38. doi: https://doi.org/10.1263/jbb.101.38

98. Choi, H., Kim, S., Son, J., Hong, S., Lee, H., Lee, H., Enhancement of paclitaxel production by temperature shift in suspension culture of Taxus chinensis, Enzyme Microb. Technol. 27 (2000) 593. doi: https://doi.org/10.1016/S0141-0229(00)00255-6

99. Rahimi, A., Hosseini, S. N., Karimi, A., Aghdasinia, H., Arabi Mianroodi, R., Enhancing the efficiency of recombinant hepatitis B surface antigen production in Pichia pastoris by employing continuous fermentation, Biochem. Eng. 141 (2019) 112. doi: https://doi.org/10.1016/j.bej.2018.10.019

100. Kangwa, M., Yelemane, V., Polat, A. N., Gorrepati, K. D. D., Grasselli, M., Fernández-Lahore, M., High-level fedbatch fermentative expression of an engineered Staphylococcal protein A based ligand in E. coli: Purification and characterization, AMB Express. 5 (2015) 70. doi: https://doi.org/10.1186/s13568-015-0155-y

101. Bojorge, N., Valdman, B., Acevedo, F., Gentina, J. C., A semi-structured model for the growth and $\beta$-galactosidase production by fed-batch fermentation of Kluyveromyces marxianus, Bioprocess Eng. 21 (1999) 313. doi: https://doi.org/10.1007/PL00009076

102. Srinivasan, S., Barnard, G. C., Gerngross, T. U., Production of recombinant proteins using multiple-copy gene integration in high-cell-density fermentations of Ralstonia eutropha, Biotechnol. Bioeng. 84 (2003) 114. doi: https://doi.org/10.1002/bit.10756

103. Lee, C. Y., Nakano, A., Shiomi, N., Lee, E. K., Katoh, S., Effects of substrate feed rates on heterologous protein expression by Pichia pastoris in DO-stat fed-batch fermentation, Enzyme Microb. Technol. 33 (2003) 358. doi: https://doi.org/10.1016/S0141-0229(03)00146-7

104. Peng, L., Zhong, X., Ou, J., Zheng, S., Liao, J., Wang, L., $X u, A$., High-level secretory production of recombinant bovine enterokinase light chain by Pichia pastoris, J. Biotechnol. 108 (2004) 185. doi: https://doi.org/10.1016/j.jbiotec.2003.11.004

105. Resina, D., Cos, O., Ferrer, P., Valero, F., Developing high cell density fed-batch cultivation strategies for heterologous protein production in Pichia pastoris using the nitrogen source-regulated FLD1 Promoter, Biotechnol. Bioeng. 91 (2005) 760. doi: https://doi.org/10.1002/bit.20545

106. Heo, J.-H., Hong, W. K., Cho, E. Y., Kim, M. W., Kim, J.Y., Kim, C. H., Rhee, S. K., Kang, H. A., Properties of the Hansenula polymorpha-derived constitutive GAP promoter, assessed using an HSA reporter gene, FEMS Yeast Res. 4 (2003) 175 doi: https://doi.org/10.1016/S1567-1356(03)00150-8

107. Li, Y., Chen, J., Mao, Y.-Y., Lun, S.-Y., Koo, Y.-M., Effect of additives and fed-batch culture strategies on the production of glutathione by recombinant Escherichia coli, Process Biochem. 33 (1998) 709. doi: https://doi.org/10.1016/S0032-9592(98)00038-7 